\title{
Shakespeare and Ibsen: A Comparative Study of Macbeth and Hedda Gabler from 21st Century Radical Feminism Perspective
}

\author{
Md. Amir Hossain \\ Department of English, IBAIS University, \\ (International Business Administration and Information System) \\ Uttara Unit, Dhaka \\ Arburim Iseni, $\mathrm{PhD}$ \\ Department of English Language and Literature \\ Faculty of Philology. State University of Tetova, Tetova, Macedonia \\ Liljana Siljanovska, PhD \\ Department of International Communication, Faculty of Languages, Cultures and Communications \\ South East European University Tetova, Macedonia \\ Vlera Ejupi, PhD \\ Department of English Language, Faculty of Languages, Cultures and Communications \\ South East European University Tetova, Macedonia
}

Doi:10.5901/jesr.2014.v4n4p30

\section{Abstract}

In this paper, our purpose is to depict the feminist message as articulated in Shakespeare's Macbeth and Ibsen's Hedda Gabler by portraying Lady Macbeth and Hedda Gabler who are representatives of Elizabethan England and the 19th century Scandinavian Bourgeois society and culture respectively. Through these female protagonists, both dramatists wanted to expose their contemporary situation of the female community. Both Hedda and Lady Macbeth have raised a fiery voice or initiated a dreadful revolution against the patriarchal rule, power, and domination with a view to attaining self-pelf, self-power, and self-domination. In these two plays, both Shakespeare and Ibsen have prioritized the female identity, revolt, and dominance more than the male order and custom. This paper also aims to discuss the character of Lady Macbeth as the matriarchal influence upon the patriarchy, the ambitious crime, woman's idea upon masculinity, Lady Macbeth's effort to repudiate womanhood, her femininity versus her unnatural resolve, her fear and remorse, her sleep-walking; Hedda is also viewed as a maladjusted, neurotic, unfulfilled, unnatural woman, full of nervous energy and longings-gliding to irresistible selfdestruction. Here, I have tried to highlight the critical judgments of several critics based on the character-analysis of the two powerful female protagonists. Considering the femme fatale characters of Shakespeare and Ibsen, the most renowned and powerful playwrights writing in English and Norwegian language respectively, especially the powerful and domineering female protagonists cum heroines, Lady Macbeth and Hedda Gabler, this paper proposes to draw attention to the play-texts of both dramatists as the embodiment of the 21 st century radical feminism as well.

Keywords: "Lady Macbeth", "Hedda Gabler", Shakespeare, Ibsen, and Post-Feminism

\section{Introduction}

Both Shakespeare and Ibsen are the most powerful and well-known playwrights in the history of English Literature. Shakespeare is the dramatist of the Elizabethan England and Ibsen, the dramatist of the 19th century Scandinavia. As dramatic artists, both of them have earned popularity and reputation around the universe. Their plays have been translated, performed and transfigured in many parts of the universe. We sense that their attitudes, in writing plays, differ in many ways, especially societal, political, economic, familial, feministic questions and so on. In this paper, our psychology is to focus on feministic message as articulated in the powerful female characters, Lady Macbeth in Macbeth and Hedda Gabler in Hedda Gabler respectively. Here, I will let you know Shakespeare and Ibsen as dramatists; analytical character-study of Lady Macbeth and Hedda Gabler along with literary criticism; comparative and contrastive 
study between these powerful women from feminism perspective in a sequential manner.

Shakespeare's greatness and pre-eminence as a dramatist are universally recognized. Every element of his drama might, in isolation, be matched by the best of his contemporaries. What is distinctive concerning Shakespeare is his combination of all gifts which were scattered in the works of other playwrights of his time. He is superior to others by his many sided curiosity and extreme diversity of his talent. His genius is flexible to a marvelous degree. He adapted himself to the most diverse material and seemed to use it all with equal skill and enthusiasm. His great tragedy, Macbeth is distinguished by such astonishing variety of kind, presentment, and dramatic movement that hardly any one formula fits them all. He shows equal aptitude for the tragic and the comic, the sentimental and the burlesque, lyrical fantasy and character-study, portraits of female and of male.

Shakespeare's representation of women, and the ways in which his female roles are interpreted and enacted, have become topics of scholarly interest. His heroines encompass a wide range of characterizations and types. Within the gallery of female characters, Shakespeare's women characters display great intelligence, vitality, and a strong sense of personal independence. These qualities have led some critics to consider Shakespeare a champion of womankind and an innovator who departed sharply from flat, stereotyped characterizations of women common to his contemporaries and earlier dramatists. Contrastingly, other commentators note that even Shakespeare's most favorably portrayed women possess characters that are tempered by negative qualities. They suggest that Shakespeare was not free of misogynistic tendencies that were deeply seated in the culture of his country and era. William Shakespeare lived during the Elizabethan era and wrote all his works based on the society of that time. The Elizabethan era was a time when women were portrayed to be weaker than men. During that time, it was said that "women are to be seen, and not heard." In this paper, an attempt has been taken to explore Shakespeare's presentation of woman, Lady Macbeth in his tragedy, Macbeth demonstrating his philosophical viewpoints concerning woman and domineering roles in the male dominated society of the Elizabethan England.

Henrik Ibsen (20 March 1828-23 May 1906) was a major 19th century Norwegian playwright of the realistic plays. Ibsen is often referred to as the "father of modern drama" and is one of the founders of modernism in the theatre. Ibsen is held to be the greatest of Norwegian author, celebrated as a national symbol by Norwegians, and one of the most important playwrights of all time, and many regard him as a feminist author. His plays can be viewed as a gallery of portrait of various kinds of male and female through being trapped in societal realism and caught in the triviality of human life while struggling to seek out truth and freedom. Among Ibsen's dramatic roles, the unusual Scandinavian women of strong characters are marked with great devotion towards their ideals and enormous resolution in pursuit of individual freedom and existence. They are actually bold, rebellious and revolutionary women warriors with independent and intelligent psychology and aspiration for the spiritual emancipation.

With their strong personalities, women are usually doomed to be trapped in a male - centered society where they are deprived of the basic right as human beings in its full sense. Ibsen has insightfully described a range of rebellious characters and unveiled the spiritual pilgrimage; they have gone through in their persistent pursuit of emancipation, freedom and in their bitter struggle to regain their identity as human beings. It was Ibsen who gave women a vigorous and fairy voice by creating the powerful women characters including Nora Helmer in A Doll's House (1879), Mrs. Alving in Ghosts (1881), Rebecca West in Rosmersholm (1886), and Hedda Gabler in Hedda Gabler(1890) with a view to breaking conventional custom and conservatism, and to focus on how women lagged behind male.

Henrik Ibsen's Hedda Gabler is one of the most criticized feminist plays, where the dramatist has explored a difference between patriarchy and matriarchy of the $19^{\text {th }}$ century Scandinavian Bourgeois society. And, Ibsen has emphasized much more on matriarchal power and domination than patriarchal system and order. According to many, the female protagonist, Hedda Gabler is viewed as femme fatale character. Being based on her character, this paper aims at finding out the power structure of Hedda in the play, Hedda Gabler. From the very beginning, Hedda has possessed both the characteristics of a rebellious personality and those of an ordinary angel like woman. She is a more pronounced type of the perverse erotic or anti-social woman than Ibsen has ever created.

Now, we will uphold Lady Macbeth's personality on whom many critics and scholars have commented in many ways:

\section{Lady Macbeth}

The historical records reveal that the position of women in the society was extremely miserable. Women occupied a very inferior position and were always oppressed. It was a natural phenomenon and practiced in every house-whether rich or poor. Shakespeare, the greatest dramatist, observed it very minutely and represented it carefully in his works. Shakespeare shows the powerful aspect of a female character, Lady Macbeth in his famous tragedy, Macbeth. According 
to Virginia Woolf, Shakespeare is the writer who made his writings transparent and free of any personal vices for delineating the women characters in his tragedies, Hamlet, Othello, King Lear and Macbeth. Shakespeare, with his extraordinary genius for portraying human behavior, depicts the condition of women in a patriarchal society and his women characters who in their richness transcend the limitations of time and Shakespearean theme becomes the legendary.

In Macbeth, Lady Macbeth is one of the most confusing and intriguing in all of Shakespeare's women. Directors and actors cannot even agree as to whether or not she is a prominent character, as she disappears after the banquet scene not to reappear until the infamous sleepwalking scene. Lady Macbeth's disruption to the political culture stems from her ambition, and this virulent ambition is made highly unnatural by her gender. When she reads Macbeth's revelation of the Witches' predictions, she immediately assumes that only her insistence will lead Macbeth actively to pursue and acquire the desired kingly position of power and authority. Lady Macbeth claims an ability to wield the character of Macbeth to her purposes and goals. Tennenhouse describes her characterization in influential political terms: "At the outset of Macbeth, Shakespeare gives Lady Macbeth the very same elements which other Jacobean playwrights use to display the absolute power of the state. He shows how these might be used subversively" (Das 46). Certainly, Lady Macbeth's suggestions are subversive that she leads her husband into murdering the rightful, current monarch in their home. With this ploy, she assumes the absolute power of the state by acting as if she were accountable to none and deserves no censure. She rises to the throne only by the virtue or vice of her husband's ascension as king, and yet, her insistence provides the impetus for the power base. Thus, Lady Macbeth exemplifies a negative symbol of female ambition and power from the Renaissance perspective. In considering Lady Macbeth's characterization, one must remember, first and foremost, that feminine desires for power were seen as unnatural. In fact, Shakespeare couches these desires in emasculating terms to give them increased gravity. Lady Macbeth repudiates her femininity for power:

Come you spirits

That tends on mortal thoughts, unsex me here;

And fill $m e$, from the crown to the toe, top-full

Of direst cruelty! (I.v.40-43)

When Lady Macbeth desires to be "unsexed," her words reveal the assumed discordance between feminine nature and political ambition. By putting these desires in masculine or gender-neutral form, Lady Macbeth explicitly suggests their unnaturalness. Shakespeare's language here induces tension and reflects the political gender tensions already existent in the Elizabethan world. Wallace MacCaffrey comments upon this disparity between femininity and political strength in the biography of Elizabeth I: "For a woman the demands made on the occupant of the throne were supremely difficult to meet, since the characteristic qualities which a monarch was expected to display were largely masculine" (Das 46). While Lady Macbeth wishes to be "unsexed," Elizabeth asserted the title King as frequently as Queen and sought to establish her own power by transcending the gender issue. Nonetheless, as Levin notes, not even Elizabeth could escape her femininity: "Elizabeth might incorporate both male and female in her sovereignty, but her body was a very human female one and, hence to both Elizabeth herself and to her people, an imperfect one" (Das 46). Just as Elizabeth had difficulty asserting political authority as a woman, and thus adopted male gender characteristics, Shakespeare defeminizes Lady Macbeth. His representation of women in his tragedy upholds her ambitious credibility. Such unnatural positioning created tension in the play and reflected anxiety in the Elizabethan world.

Shakespeare pushes Lady Macbeth's oddity so far as to reverse Macbeth's gender roles. In the play, Macbeth, Lady Macbeth is considered nearly sinister in comparison with her husband, Macbeth, a perception that is supported by such assertions as from the lips of her character. Indeed, Macbeth demonstrates considerably less determination than his wife. Macbeth's self-doubting statement of "Each corporal agent to this terrible feat/Away, and mock the time with fairest show/False face must hide what the false heart doth know :"( I.vii.80-82) As he is considering the grave deed, he and Lady Macbeth have connived to commit, indicating his awareness of the negative consequences, he is likely to suffer, even if unspecific. As a result, Lady Macbeth scorns him for his mental weakness. In bloodying her hands in the death of the king, she chastises her husband: "My hands are of your color; but I shame/To wear a heart so white" (II.ii.63-64). Typically, weakness is associated with the female, and man gains integrity through strength and boldness in battle. But Macbeth loses his courage at the decisive moment and Lady Macbeth assumes his bloody obligation. Her husband's weakness is not only shameful in Lady Macbeth's attitudes; his weakness is also as unnatural as her strength. Such a reversal carries with it significant social ramifications. Tennenhouse comments upon the gender reversal and its political symbolism:

Most other Jacobean tragedies presuppose this same connection between sexual relations and the condition of the political body. In staging Macbeth, Shakespeare simply literalizes the homology which makes unruliness on the part of an 
aristocratic woman into an assault on the sovereign's power. He allows Lady Macbeth to overrule her husband in order to show that such inversion of sexual relations is also an inversion of the political order. Her possession of illicit desire in its most masculine form- the twisted ambition of the malcontent leads directly to regicide (Das 47-48).

Positioning woman over man has not just domestic but political connotations as well. Lady Macbeth's dominion over Macbeth reflects the larger issue of female involvement in the political structure and a woman's possible dominion as monarch over man as subject. Lady Macbeth's strength deteriorates as she falls into periods of lunacy and sleepwalking. Lady Macbeth postulates that "none can call our power to account," (V.i.37) but apparently, she mistakes the power of her own conscience. Her manic fixation with bloodied hands and her final act of suicide indicate a personal trial and conviction. A famous critic, Sarah Siddons has expressed pardon of Lady Macbeth's words and behavior by emphasizing that it is ambition that drives Lady Macbeth. Siddons believes that Lady Macbeth's mention of a nursing child in the midst of her dreadful language persuades one unequivocally that she has really felt maternal yearning of a mother towards her babe. Siddons further points out that "it is only in soliloquy that she (Lady Macbeth) invokes the powers of hell to unsex her." In 1785, Sarah Siddons played Lady Macbeth to her brother John Kemble's Macbeth. Siddons was said to have been the only woman who could ever play this role. She was a strikingly beautiful woman, very tall and statuesque. The $18^{\text {th }}$ century Shakespeare-scholar, William Hazlitt said of Siddons, "We can conceive of nothing grander. It seemed almost as if a being of superior order had been dropped from higher sphere to awe the world with the majesty of her appearance. Power was seated in her brow, passion emanated from her breast as from a shrine. She was tragedy personified." Siddons' choice made Lady Macbeth a ruthlessly ambitious woman who dominated her husband. Her brother's Macbeth was said to have been in a constant state of blindly rushing towards and from his ambitions. Siddons countered this by being absolutely firm and even masculine in her desires. She became the strongest of the pair.

Hazlitt said, "She is a great bad woman, whom we hate, but whom we fear more than we hate." This fear came from her utter steadiness. Lady Macbeth seems to know that she will need to coax him into performing the murder of Duncan. She decides what needs to be done and she "chastise[s] with the valor of her tongue" every fear and doubt Macbeth has about performing that deed. The choices made by Siddons of masculinity and steadiness seem to be found in Lady Macbeth's famous "unsex me" speech. She demands the forces of evil to neuter her, to free her of gender, and the frailty of womanhood. Lady Macbeth, often, in the script, takes charge of the situation. Siddons read this to mean Lady Macbeth was in charge at all times. She chose to make Lady Macbeth the dominant figure in the relationship. More evidence for Lady Macbeth's dominance may come from her constant questioning of Macbeth's manhood. It is the strike she makes most often to push him into action. Macbeth falls for it every time. Again, it seems as though Siddons chose to believe that it is a constant part of their relationship.

Hazlitt has compared Lady Macbeth with the three Witches. According to this critic, Lady Macbeth's solid substantial displays of passion, and the uncontrollable eagerness of anticipation when she receives her husband's account of the predictions of the Witches, show a striking contrast to the cold malignity of the Witches who are equally instrumental in urging Macbeth to his fate. The Witches urge Macbeth to evil because of their love of mischief and because of a motiveless delight in deformity and cruelty. They are hags of mischief; they are malicious because of their incapacity to enjoy any simple pleasure and they are enamored of destruction for its own sake. But Lady Macbeth urges Macbeth to evil because of the force of her passion. Her fault seems to have been an excess of the strong principle of self-interest and family advancement which does not recognize the common feeling of compassion and justice. A passing reflection, on the resemblance of the sleeping Duncan to her father, alone prevents her from murdering Duncan with her own hand.

According to S.T. Coleridge, Macbeth is described by Lady Macbeth in such a way that in the process she also reveals her character. Lady Macbeth, like all in Shakespeare, is a class individualized: -- of high rank, felt mush alone, and feeding herself with day-dream of ambitions; she mistakes the courage of fantasy for the power of bearing the consequences of the realities of guilt. Hers is the mock fortitude of a mind deluded by ambition; she shames her husband with a superhuman audacity of fancy which she can not support, but she sinks in the season of remorse, and dies in the suicidal agony. Her speech: "Come all you spirits/That tend on mortal thoughts, unsex me here....." (Lall 150) is that of one who had habitually familiarized her imagination to dreadful conceptions, and was trying to do so still more. Her innovations and requisitions are all the false efforts of a mind accustomed only hitherto to the shadow of the imagination, vivid enough to through the everyday substances of life into shadow, but never as yet brought in to direct connect with their own correspondent realities. She gives no evidence of a womanly life, no wifely joy at the return of her husband, no pleasure terror at the thoughts of his past dangers, while Macbeth bursts forth naturally: "My dearest love ......" (p.150) and shrinks from the boldness with which she presents his own thought to him. With consummate art, she at first uses as incentives the very circumstances (such as Duncan's coming to their house) which Macbeth's conscience would most probably have mentioned to as motives of abhorrence or repulsion, but Macbeth is not yet prepared and says: "We will 
speak further" (Lall 150).

The critic, M. Leigh-Noel, in her study of Lady Macbeth, offers further defense by considering Lady Macbeth's circumstance of socioeconomic position and history, as well as on her own assertion that Lady Macbeth had been a mother. Noel suggests that, in the age that Macbeth was written "human life was by no means as sacred as it is now; and that violence was the common resort of both mean and noble in their efforts to gain the desires of their souls." Noel places emphasis on Lady Macbeth being the "solitary inmate" of Macbeth's castle, believing she was "cheered only by occasional and fitful visits from her husband." Noel further suggests that Lady Macbeth had to "live only on the remembrance of the bittersweet joy of maternity, to wake up and miss the magnetic pressure of infant fingers" consequently, causing Lady Macbeth to cling "more tenaciously to her husband" (Thompson \& Roberts 174). Noel believes that these circumstances support the theory that Lady Macbeth paid "a terrible price . . . to gratify her husband's ambition." That while " Macbeth had the stronger wishes, she (Lady Macbeth) had the stronger will" (Thompson \& Roberts 175) and since it is will that prevails over wishes, Lady Macbeth's share of the burden in her conspiracy with her husband outweighed that of Macbeth's.

Shakespeare's Representation of Women in his Tragedies Noel's arguments validly challenge many common perceptions of Lady Macbeth and rightfully points to isolation and suffering as likely contributors to Lady Macbeth's loss of mental capacity. But it is the shocking threat Lady Macbeth made regarding dashing the brains of her nursing child that the critic, France Anne Kemble believes is "no mere figure of speech" continues to cast Lady Macbeth as a character who is much worse that her male counterpart.

Harold Bloom, in The Invention of the Human, brings up idea that informed and even translated directly into the creation of Lady Macbeth. One common idea he presents is that Macbeth is her second husband. He claims that Macbeth is dependent on Lady Macbeth. He comes to her first with the Witches' promise. He is led by her insistence of their steps to power. His dependence on her also allows for a greater sense of loss for Lady Macbeth when he starts to exclude her from plans. If, after the murder, he no longer needs her, the steps to her decline seem clear. She has gone from his trusted, needed advisor to a wife who is purposefully being left out. Bloom refers to Lady Macbeth as "pure will." The lack of will that Macbeth seems to have succumbed to is what makes Lady Macbeth so necessary to him, particularly early on. She lets her desire to be queen drive her and her husband to regicide in her home. It seems that Macbeth could not have gotten to that point by himself. He says that he had been honored and it wasn't yet time to give up those honors, even though she is suggesting greater honors. Macbeth and Lady Macbeth are the happiest couple in all of Shakespeare. He calls them, "... persuasive and valuable personalities, profoundly, in love with each other." This statement, particularly, informed the choices for Lady Macbeth. In this case, the idea that they loved each other seemed more useful than the idea that she was a mother figure for Macbeth, or that she needed him to achieve her political goals, or that it was a lust/sex based relationship. She has to scold him at times for being afraid and for getting upset. She does send him to bed, like a mother, after the disastrous banquet. Her need for Macbeth as her way into power is obvious that she cannot gain power as a woman without a man. She needs to be married to man who can get her to the top. She got lucky with a powerful man whom she also deeply loves.

Dr. Samuel Johnson has commented that the argument, by which Lady Macbeth persuades her husband to commit the murder, affords a proof of Shakespeare's knowledge of human nature. She urges the excellence and dignity of courage, a glittering idea which has dazzled mankind from age to age; but this sophism Macbeth has ever destroyed, by distinguishing true from false fortitude, in a line and a half; of which it may almost be said that they ought to bestow immortality on the author even all his other production had been lost:

I dare do all that may come a man;

Who dares do is none. (I.vii.46-47)

This topic, which has been always employed with too much success, is used in this scene, with peculiar propriety to a soldier by a woman. Courage is the distinguishing virtue of a soldier, and the reproach of cowardice cannot be borne by any man from a woman without great impatience.

She, then, urges the oaths by which he had bound himself to murder Duncan, another art of sophistry by which man had deluded their consciences, and persuaded themselves that what would be criminal in others is virtuous in them; this argument Shakespeare, whose plan obliged him to make Macbeth yield, has not confused, though he might easily have shown that a former obligation could not be nullified by a latter [...]

The passions are directed to their true end. Lady Macbeth is merely detested; and though the courage of Macbeth preserves some esteem, yet every reader rejoices at his fall. Thus, Shakespeare's drama reflects the Elizabethan world. Within the play Macbeth, one sees potential conflicts arising from female ambition for sovereign power and corruption of 
the politic body through corruption of the female sovereign body. In this play, Shakespeare mirrors anxiety from within the Elizabethan culture relating to the existence and dependence upon a female monarch. Also, the play ends with the diminution of female sovereign authority and an apparent return to a state of normalcy within a more traditional, patriarchal framework. This return to patriarchy represents both Shakespeare's political resolution and the Elizabethan cultural desire.

Shakespeare realizes that throughout the history of mankind, women have always been at a disadvantageous position socially, economically and politically. Through strong female characters, Shakespeare has delineated gender issues. He has given a comprehensive view of life with equal emphasis on both male and female characters. His female characters show the social stigmas they have undergone during that time. He has portrayed his personal admiration for intelligent, strong women, using virtues and strength he gives his female characters. So, we can say that Shakespeare should be considered one of the pioneers of feminist movement. Actually, through representation of women characters in the tragedies, he wants the elimination of gender discrimination and advocates the true liberation of women in patriarchal society.

Now, this paper also aims at discussing on the character of Hedda Gabler along with literary criticism:

\section{Hedda Gabler}

Henrik Ibsen's Hedda Gabler is one of the most controversial feminist plays, where the dramatist has unveiled a difference between patriarchy and matriarchy of the $19^{\text {th }}$ century Scandinavian Bourgeois society. And, Ibsen has emphasized much more on matriarchal power and domination than patriarchal system and order. According to many, the female protagonist is viewed as femme fatale character among Ibsen's women. Being based on her character, this paper highlights the empowerment of Hedda in the play, Hedda Gabler.

In "Preface to Hedda Gabler," William Archer claims that "the environment and subsidiary personages" are "all thoroughly national" or "Norwegian." Archer thinks that "Hedda herself is an international type; a product of civilization by no means peculiar to Norway" (Arches, XII, quoted in Hossain 28). Archer finds Hedda not only "international," but "modern" also, "particular traits and tendencies of the Hedda type are very common in modern life." What Archer writes further confirms our estimate of a power-monger about Hedda, but this is a unique complicated kind of power:

Hyperesthesia lies at the root of her tragedy. With a keenly critical, relentlessly solvent intelligence, Hedda combines a morbid shrinking from all the gross and prosaic detail of the sensual life. She has nothing to take her out of herself - not a single intellectual interest or moral enthusiasm ... Her malign egoism rises up uncontrolled, and calls to its aid her quick and subtle intellect (Gosse XVIII-XIX, quoted in Hossain 28).

From draft material of Hedda Gabler, we can find that there is "extensive," "including a complete draft version of the play, a number of revisions of the draft, together with two notebooks of notes and jottings and trail dialogue" (McFarlane 286-87, quoted in Hossain 28). One of the entries in Ibsen's two notebooks reads: "The 'demonic' thing about Hedda is that she wants to exert an influence over another person." And, this not only justifies us in our sense of a demon about Hedda, but also provides a big basis for one's going by the idea of power - the drive to "exert an influence on others" - in explaining the whole Ibsen's works. James McFarlane, in his "Drama and the Mind: Hedda Gabler" in Ibsen and Meaning Studies, Essays and Prefaces, places ideas enough for one's feeling like doing so. For McFarlane considers Hedda to be "a means serving much more general and characteristically Ibsenist idea." And, also that "consequently the other characters in the play, far from being merely 'feeds' or foils to Hedda, are themselves essential and integral to a full articulation of the statement; the play is concerned to make." McFarlane calls the play a "dramatic account of certain proceedings: the history of Hedda's bid for control of Lovborg, of the savagery of her failure, and of its consequences" (McFarlane 286- 87, Hossain 29). McFarlane comes to inform us how any such conduct as is found in Hedda "had always roused Ibsen to fury: any interference of this order in other people's lives, any tampering with their liberties or their efforts at self-realization, particularly if done under the guise of altruism or in the name of righteousness, at once drew his anger" (McFarlane 286-87, quoted in Hossain 29).

Hedda is highlighted in the whole world - literature, one unique scope for probing into demonic aspects of human character. As is expected from the dialectically solid formation of any such character, Hedda is dominating not towards any one or single person. And, her husband Tesman is no less a victim, "only that in his case one can see how, once the domination is asserted and assured, there is only contempt for the victim" (McFarlane 288). Hedda has been shown connected by Ibsen with her father, an army General and an obviously powerful person. Ibsen's stage-direction reads: "By the back wall of the inner room, a sofa, a table and a couple of chairs can be seen. Above the sofa hangs the portrait a handsome elderly man in a general uniform. Above the table, a hanging lamp with an opalescent glass shade" (Act I, 290). A note to this part of the stage - direction reads as follows: 
As the only completely personal object on display, the portrait takes on particular importance for a viewer. Conventionally, such a portrait would represent the present owner of the house or his ancestor, but as the content gets filled in, it comes to represent both Hedda's upbringing and the biological influence on her personality: the twin bases of Naturalistic characterization as well as explaining her "unfeminine" desires and acts. Its presence in the inner room also marks this as specially Hedda's space, private, even interior in the sense of being inside her psyche.

The uniform in the portrait is also a visual clue to the values. Hedda has derived from her father: in the $19^{\text {th }}$ century most generals were aristocrats, who commanded men (Innes 114).

Hedda has been shown by Ibsen connected with her powerful father in a very remarkable way; one gets this in the very name she has been given by Ibsen. Another note prepared for the title of the play given below:

Properly speaking, the name of the heroine should be "Hedda Tesman" since at the date of the play; women automatically took their husband's surname on marriage. Ibsen pointed out to his German translator that the title is intended to emphasize that she is her father's daughter.

The title also signals Hedda's unconventional nature and her assertion of her own individuality in opposition to social convention - in contrast to Thea, who insists on being called Mrs. Elvested in spite of having left her husband. It is also possible to deduce from the title that this is "a character-study pure and simple ..., which goes along with Ibsen's principle of dramatic composition that the play "proceeds from the individual" (Innes 114).

The play, Hedda Gabler (1890) offers a rich literary text for decoding the hidden messages, about human consciousness and constructing the indicated meanings about human existence, especially from the perspective of feminist theory. Hedda, one of Ibsen's controversial female characters, can be explored from a new sort of feminist perspective, or even beyond the traditional feminist critical convention of man/woman duality. According to Xu Yanhong, an Ibsen scholar, Hedda is one of the boldest dramatic characters among Ibsen's women. She can be viewed both as a feminist and as an ordinary woman. Hedda Gabler is characterized as a perverse, exasperated and irreconcilable young lady. All this distinguishes her from ordinary women, and undoubtedly, endows her with a sort of rebellious feminist spirit. Although Ibsen himself does not intentionally advocate feminist doctrines, his sympathetic portrayal of this character might betray his original intention. To make the story more dramatic, Ibsen grants Hedda a soul craving for beauty and freedom which an ordinary young woman usually possesses. From the very beginning, Hedda has both the characteristics of a rebellious woman and those of an ordinary angel - like woman.

Tragedy is created only when such a figure of strong character and free soul is caught between her unconventional and unrestrained former flame [Lovborg] and her dull and mediocre husband [Tesman]. She is torn between the suffocating societal reality and her liberating spirit. It is meaningful that the play ends with her suicide by a single shot, she breaks away forever from the uninviting and boring banquet of life. Her death is indeed obscure to the audience but if we realize the above two aspects of her character, we understand easily why she has gone to the extreme; even in her attitude toward death, she distinguishes herself from ordinary women. This tragic figure is approached as a prospective feminist who is caught between the repressing $19^{\text {th }}$ century Bourgeois society and her own desire and longing for freedom; she awakens like autumn leaves with the triviality and boredom which feature her immediate surroundings --her family and social relations, and acquaintances - torturing her independent and rebellious mentality. And, she comes to collapse when her aspiration for emancipation and her expectation for a meaningful and fulfilling life are shattered to pieces at the end of the play.

In Hedda Gabler, we deal with a more complex, intricate character. The eponymous heroine has been variously interpreted by critic and actress as a 'caged tigress' a hooded cobra, or a cruel princess. Many (male) critics are ready to view Hedda as a demonic character, a counter - foil to the "Doll-like" Nora. Rather personal tragedies in the form of nature, propensity, and personality- interact with the social environment in the form of lack of space, and lack of possibilities to produce surpassing drama:

'Vivid, anguished dangerous' - Hedda is all of these. But, she is also complicated and natural. She suffers, she struggles, she is human - 'neither good nor evil - a bundle of unresolved tendencies, a human being in process of development, conditioned by heredity, limited by environment ... striking out blindly in search of fulfillment (Ahmed 126).

Personally, Hedda is face to face with an inner ability to draw sustenance from the destiny sees fit to bestow on each individual. But socially, one cannot help feeling. Hedda is gazing out of the window to a world where woman has to conform to a rigid, familial, sexual, emotional, intellectual role, circumscribed by a dependent status on a husband; one has to 'pray' on. Hedda gazes at the world denied to woman, the world that may be but has not been born. Hedda's transformation into the new-woman never even takes off. A very sobering thought for one who undertakes a feminist reading of Ibsen's play, Hedda Gabler.

Hedda uses her authority over Tesman, Lovborg and Thea Elvested. As Hedda watches all the characters from a vantage point, she fails to realize that she is not only being watched by Brack, it is also being judged. Hedda, symbol of 
physical representation of power, controls all other characters through her visible/invisible presence. Berta, the old maid is perturbed because she thinks she fails to satisfy Hedda. David Thomas comments on Hedda Gabler:

Hedda physically manipulates all the stage space given to the play. In Act II, she cleverly directs Brack and Tesman to use her upstage room for punch and cigars so that she can use the drawing room for her encounter with Lovborg. In all three Acts, she bullies Thea into sitting or standing in positions where she can dominate her. In Act IV, however, this changes drastically. As the consequences of her actions become known -the destruction of Loborg's manuscript and his subsequent death she loses her previously dominant status. While the others literally pick up the shattered pieces of what Hedda has destroyed, she finds herself treated like the irresponsible child; she has become (Thomas 89-90, quoted in Zaman 82-83).

Thomas also explains how from this point onwards other characters intrude into the circle of dominance created by Hedda. With the excuse of putting together the notes of Lovborg, Tesman and Thea take their positions in Hedda's private room. Thomas points out that as Hedda takes refuge by the stove Brack "stands over her menacingly, quietly making oblique sexual threats" ( Zaman 90). Interestingly, after losing emotional control over other characters, Hedda loses physical control even over the interior of her house. Death and the mechanisms of power go hand in hand and Hedda, who desires so much to control the lives of other people, has to kill herself. Though Hedda shows her nonchalance to the whole affairs at the very beginning, she is the one who burns Lovborg's forthcoming book. This book is something about which Lovborg is so proud. Hedda burns the book - this should be seen in relation to the fact that Thea has beautiful hair that Hedda threatens to burn. However, it is Tesman who sits after the death of Lovborg with Hedda to page together the book that has turned into ashes. This threatens Hedda's position. She fears to be defeated by Thea. Hedda's choice of committing suicide shows that individuals like her are never accepted by the conventional and disciplinary society. She has been dominating people around her, though by the power of sexuality. Hedda is challenged by a male authority figure Brack, who tries to blackmail her to subjection.

From above discussion, we may realize that Ibsen's Hedda Gabler, one of the most powerful women in his plays, who never surrenders herself to male domination and order, through this character we can understand that Ibsen has emphasized on matriarchy rather than patriarchy. Ibsen's feminist creation-Hedda is one of the most controversial female characters of his women. Many famous critics have commented on Ibsen's Hedda Gabler differently. In this paper, I will discuss the critical judgments of several critics concerning Hedda Gabler:

In "Ibsen's New Drama", Sir Edmund Gosse points out that Hedda is one of the most singular beings whom Ibsen has created. She has a certain superficial likeness to Nora, of whom she is, indeed, a kind of moral parody or perverted imitation. Hedda Gabler is a spoilt child, whose indulgent father has allowed her to grow up without training of any kind. Superficially, gracious and pleasing, with a very pretty face and tempting manners, she is devoid of moral sense in reality wholly. She reveals herself, as the play proceeds, as without respect, for age or grief, without natural instincts, without interest in life, untruthful, treacherous and implacable in revenge. She is a very ill-conditioned little social panther or ocelot, totally without conscience of ill or preference for good, a product of the latest combination of pessimism, indifferentism and morbid selfishness all claws and this for blood under the delicate velvet of her beauty.

Hedda Gabler is a more pronounced type of the perverse erotic or anti-social woman than Ibsen has ever created. Through depicting Hedda Gabler, Ibsen seems to have expended his skill on the portrait of a typical member of that growing class, peculiarly frequent now-a-days the simple and masculine doctrines of obedience to duty, of perseverance, of love to mankind, are in danger of being replaced by "a complicated and sophisticated code which has the effect of making some of us mere cowards in the face of difficulty and sacrifice, and of disgusting all of us with the battle of life". In the play, Hedda Gabbler, we can see the religious idea violently suppressed under the pretext of a longing for liberty. She will not be a slave, yet is prepared for freedom by no education in self- command. In stead of religion, morality, and philosophy, her head is feverishly stuffed with an amalgam of Buddhism and Schopenhauer. Even the beautiful conventions of manners are broken down, and the suppression of all rules of conduct seems to be the sole road to happiness. In her breast, with its sickly indifference, love awakens no sympathy; age no respect, suffering no pity, and patience in adversity no admiration (Innes 55 ).

In "On playing Hedda," Elizabeth Robins comments that Mr. Clement Scott understands Hedda? Any man except that Wizard Ibsen really understands her? That is the tremendous part of it. How should men understand Hedda on the stage when they do not understand her in the persons of their wives, their daughters, their women- friends? One lady of our acquaintance, marries and not noticeably unhappy, says laughing, "Hedda is all of us." Hedda is not all of us, but she is a good many of us. Anyway, she is a bundle of the unused possibilities, educated to fear life; too much opportunity to develop her weakness, no opportunity at all to use her best powers.

Hedda is first represented to us as an enviable person. We hear of what General Gabler's daughter has "been accustomed" to; how fond she is of dancing and shooting at a mark and riding with her handsome father "in her long 
black habit and with feathers in her hat." It is the corrosive action of those qualities on a woman in Hedda's circumstances that makes her the great acting opportunity. She is in her revolt against those common places surroundings that the book- worm she has married thought so "elegant" her unashamed selfishness; her scorn of so- called womanly qualities; above all, her strong need to put some meaning into her life. Hedda's first and dearest dream has been to find contrasts with life through the attractive young man of letters, Eilert Lovberg that hope ends in driving him from her at the point of a pistol- not, as an eminent critic has said, "in the ostentation of outraged purity which is the instinctive defense of woman to whom chastity is not natural." Hedda drives Lovbrog from her in disgust; disgust at the new aspects of vulgar sensuality which her curiosity about life has led him to reveal. They make her gorge rise. She never denies it is her doing that he reveals these things; it is not her doing that he has them to reveal. The man who has wallowed in that filth must not touch Hedda Gabler not fresh from the latest orgy: the effect of that experience, plus the conditions of her own life and upbringing, is to throw her into marriage with the intelligible man she can find who is decent, and no one can deny that poor Tesman is entirely decent. Hedda speculates like many other women, on the opportunity politics would give to her husband, and through him, give to her; but she is too intelligent to have much hope of Tesman in that direction. She is no sooner home from her boring honey-moon than she finds that a girl she has looked down on and terrorized at schoolshrinking, gentle Mrs. Elvested.

Hedda's passion for external material beauty is not the only kind of beauty that sways her. Lovborg in his moods of poetic exaltation has given her a glorious sense of freedom, of daring. She has her phrase for those of his high moods. When Hedda asks eagerly, "Did he have vine leaves in his hair?" (Act III, 331) She is not inquiring whether Lovborg is drunk with the fiery Scandinavian punch, but whether he has tasted a diviner draught. She is using her symbol for his hour of inspired vision, which has for her, its intoxication. She has lost all that - unless she can break the hold of this irritating little goose. Thea Elvested says that she has been so frightened of Hedda at school.

It is a commentary on actress psychology that though in those days Elizabeth Robins accepts, and even herself uses, the description of Hedda as a "bloodless egoist." Ibsen's unwritten clue brings Robins close enough to the "coldblooded egoist" to feel her warm to her (Robins) touch; to see Hedda Gabler as pitiable in her hungry loneliness - to see her as tragic. She is insolent and evil. Naturally enough, no critic, so far as Robins knows, has ever noticed the governing factor in Hedda's outlook, her consciousness of one sort of power, anyway the power of escape. The reason, men have not noticed the bearing on Hedda's character, and fate seems plains enough. Certainly, the particular limitations and enslavements threaten women, who do not threaten men. Such enslavements may seem so unreal to decent men as to appear as melodrama (Innes 58-61).

In "Hedda Gabler: The Play in Performance," Janet Suzman points out that [...] Hedda is a prey woman to hers. Her strong heart pumps away inside her healthy body. She gets no ... feeling of illness from her. She suffers from an ancient disease, Accidie (i.e. sloth - one of the seven deadly sins, is like medieval medical term for listlessness, and has become used to signify a state where all the activities seem pointless since life has no purpose.) Suzman believes that Hedda cannot equate compromise with living, and in that sense is more true to herself than anyone in the play. Both Tesman and Berta adapt. Thea does anything to adapt. Eilert Lovborg tries and fails. Hedda cannot try and must not fail.

Paralyzed by her own perfectionism, tied down by the lack of alternatives, devoured by the unquestioning greedy lives around her and inside her, where Hedda is to direct that nervous animal energy of hers. She must be central to everyone's attention and not peripheral. She must know everything and commit herself to nothing. The baby forbids that it is a very committal to the future. Her final act is a combination of expertise and taste. But, it is an absolute necessity, and in that sense, it is an act of passion and commitment.

In an interview, Janet Suzman also comments that Hedda must not be played as a cold, passionless, invulnerable creature that is superior to the situation in which she finds herself. It is true that she is bored with everything around her, and contemptuous, and this may appear to give her and air of superiority in relation to the other characters, but this boredom is not a passive emotion, and in its depth and intensity, it results in an intense inner frustration that threatens to paralyze her. Hedda is very provincial as well as being the proud daughter of her father, General Gabler. She fails to make her escape into the romantic world. She imagines Eilert Lovborg inhabiting there is no horse, no new piano, no butler, no entertaining - only her guns to afford her some relief from her frustration. And, the greatest threat of all is the expected baby, which destroys all her dreams of freedom, and reduces her status to that of a provincial housewife, mother and it is Tesman's.[...]

Hedda feels trapped, and everything aggravates her situation, and when she fails to triumph over it vicariously through the suicide. She encourages Eilert Lovborg to commit. She has no alternative but to destroy herself. She sets up the scenario for her own death. Eva le Gallienne mentions in this respect that the curtains she draws, as if they were stage-curtains, before shooting herself. Hedda is a weak character in the sense that she has not the courage to face her mundane life of day- to- day existence, yet she has the courage to shoot herself. This shooting is adumbrated (i. e. to 
suggest or describe something in an incomplete way) by all unusual, "shocking", and unexpected things that she does in the play. Her weakness as an ordinary mortal and her struggle as an extra ordinary one give her, her tragic stature, and make of her an enigmatic, awesome creature. [...]

There is quite a lot of comedy in Hedda Gabler; it is an essential to it as it is, in Shakespeare. [...] Cleopatra's illusage of the messenger who brings her news of Antony is a good example. We dislike her for ill-usage of he messenger - one should not treat a servant like that but there is also something laughable about her loss of self-control and the shocked surprise of he messenger which makes us warm to Cleopatra because it reveals her as human and fallible. The scene with the aunt's hat is like that, both when she mistakes it for the servant's, and when she tells Brack later with disarming candor that the mistake was calculated. We dislike her for her spitefulness laugh at the discomfiture of the fussy aunt, and appreciate Hedda's irritability as all too human. [...] She might do so if she were not surrounded by such very unsympathetic people - the foolish pedantic husband, the smotheringly affectionate aunt with her unwelcome and arch allusions to her pregnancy, the predatory insinuating judge, the mouse like Thea. Hedda is no saint. [...] (Innes 100-101).

This paper focuses on the character of Hedda Gabler from different perspective, especially, her power structure who is the representative of the $19^{\text {th }}$ century Scandinavian Bourgeois family. Through this female protagonist, we can realize the women question of Ibsen's contemporary age. In the play, Hedda Gabler, the female protagonist has been shown as the paradigm of female power and dominance, rebellious personality, self-sacrifice soul, irresistible, undefeated modern woman. Ibsen, through the character of Hedda gabler, has tried to regenerate the revolutionary passion of a woman's potentiality and self-freedom, and female power is mostly prioritized.

\section{Comparative and Contrastive Analysis}

In Shakespearean political tragedy, Macbeth and Ibsenian domestic tragedy, Hedda Gabler, both Lady Macbeth and Hedda Gabler are the manifesto of the $20^{\text {th }}$ and $21^{\text {st }}$ century radical feminism. Through these powerful women, we can comment that they have been upheld as the sharp weapon of the feminism; they never surrender themselves to the patriarchal rule and domination, not merely that they never hesitate to sacrifice their lives for attaining their self-power, self-dominancy, and above all, self-identity. Considering the female situation of their respective period, both Shakespeare and Ibsen were self- conscious critics of society, especially for the unnoticed treatment toward women. Female were considered to be inferior being; they had no basic rights in the patriarchal order and system. These dramatists have created the two radical women with a view to awakening the neglected women's community of the Elizabethan England and the $19^{\text {th }}$ century Scandinavian society respectively. Both Hedda and Lady Macbeth have raised turbulent echoes or initiated a dreadful revolt against the male dominated norms and order with a view to unveiling universal feminism. In these two plays, both playwrights have prioritized the female identity, revolt and dominancy more than the male order and custom. Through repressing the patriarchal domination and tradition, the purpose of our paper is to focus on the feminist message as articulated in Shakespeare's Macbeth and Ibsen's Hedda Gabler. In this paper, a plan has been prepared to expose Shakespeare's treatment of woman, Lady Macbeth in his courtly tragedy, Macbeth demonstrating his thoughts concerning woman and ruling passions in the male dominated society of the Elizabethan Period. Lady Macbeth's idea of masculinity is devastatingly conventional: a man is one who is not afraid. Throughout the play, her femininity is held in juxtaposition to the unnatural forces to which she appeals. Woman is, normally, the symbol of life and nourishment; but here Shakespeare emphasizes the unnaturalness of the contraries to whish Lady Macbeth appeals.

Moreover, Hedda naturally falls into the bad woman catalogue. Hedda naturally has both the quality of strong (feminist) woman and the character of all the ordinary women. Therefore, the characterization of Hedda Gabler is by no means merely feminist-oriented. By analyzing the darling and demon in a deconstructive way, we may liberate Hedda from the demonic division, or interpret her beyond a seemingly evil image. Hedda as a woman character obviously has all the qualities of the new type of women created by Ibsen, but on the other hand, she has inherited some conventions that all women stick to. James Joyce's evaluation of 1900 is the representative of Ibsen's feminism: "Ibsen's knowledge of humanity is nowhere more obvious than in his portrayal of women. He amazes one by his painful introspection; he seems to know them better than they know themselves. Indeed, if one may say so of an eminently virile man, there is a curious admixture of the woman in his nature" (Finney 93). On the other hand, Shakespeare moulded his heroine into extraordinary women who must have been an inspiration to all women who came to see his plays. Shakespeare's portrayal of female characters is far more positive and more dignified than their portrayal in various sources. Taking into account the portrayal of the women's characters in the source and the attitude towards women and their image at the time, it is clear that Shakespeare chose to make his heroines remarkable women.

Both Lady Macbeth and Hedda Gabler want to become unsexed, and they want their milk to turn to gall. They want 
to put aside their truly feminine qualities. Both of them are dominant, high ambitious and uncontrollable type of women. With the passage of time, Shakespeare's Lady Macbeth and Ibsen's Hedda Gabler will remain "Never-fading" in the History of English Literature. Thus, we sense that in the 21 ${ }^{\text {st }}$ century, both the two women are the embodiment of radical feminism.

\section{References}

\section{Primary Sources}

Johnstan, Brian. \& Rick Davis (Trans.). Ibsen's Selected Plays. New York \& London: W.W. Norton \& Company, 1995. Printed.

MaFarlane, James. Four Majar Plays. Oxford University Press, 1998. Printed.

Shakespeare, W. The Complete Works of William Shakespeare: Hertfordshire: Wordsworth Editions Ltd. 1996. Printed.

\section{Secondary Sources}

Archer, William. "Preface to Hedda Gabler" in the Collected Works of Henrik Ibsen Vol. X. New York: Chartes Scribner's, 1906-12. Printed.

Bandyopadhay, Kazal. "Hedda Gabler. A Scathing Study of Female Power" in Spectrum Khondakar Ashraf Hossain et al. Dhaka: University of Dhaka Press, 2007. Printed.

Bloom, Harold. Shakespeare: The Invention of the Human. New York: Riverhead Books, 1998. Printed.

Das, Pragati. "Shakespeare's Representation of Women in his Tragedies" in Prime University Journal, ISSN: 1995-5332, Vol. 6, No.2, 2012. P.12. Printed.

Dall, J. "The Stage and the State: Shakespeare's Portrayal of Women and Sovereign Issues in Macbeth and Hamlet." Indiana: The Hanover Historical Review Volume 8.2000. Printed.

Engelstad, Fredrik. "The Centrality of Power in Henrik Ibsen's Dramas" in Proceeding IX International Ibsen Conference. Pal BjorbyAarseth et al. Ovre Ervik: Acedemisk Forlog, 2001. Printed.

Finney, Gail. "Ibsen and Feminism" in The Cambridge Companion to Ibsen. James McFarlane. (Ed.). New York: Cambridge University Press, 2004, 89-103. Printed.

Granville, H. Barker. Prefaces to Shakespeare. New York: Hill and Wang. 1970. Printed.

Hase, L. M. Shakespeare's Portrayal of Women: The Paradigm of extremes: The role of women in Shakespeare's plays. 2008. Printed.

Innes, Christopher (Ed.). A Routledge Literary Source Book on Henrik Ibsen's Hedda Gabler. (London \& New York: Routledge, 2003), 31-104. Printed.

Islam, Muhammad Saiful. "Hedda Gabler. An Explication of Power Games" in Centennial Essays on Ibsen Niaz Zaman et al. Dhaka: University of Dhaka Press, 2006, 81, 83-86. Printed.

Kott, Jan. Shakespeare Our Contemporary. Scranton: Norton W.W. and Company, 1974. Printed.

Lall, Ramji. (Ed.). Shakespeare's “The Tempest. Dhaka: Friends' Book Corner, 2012. Printed.

McFarlane, James. "Drama and the Mind: Hedda Gabler" in Ibsen and Meaning: Studies, Essays, and Prefaces. 1953-87. Norwick: Norvik Press, 1989. Printed.

Picdo, Maria Bonilla. "The Construction of the Sexuality in Four of Ibsen's Heroines" in The Living Ibsen: Proceedings - The 11th International Ibsen Conference. Frode Helland et al. (Oslo: University of Oslo, 2006). 395-97. Printed.

Williams, Raymond. Drama From Ibsen To Eliot. Harmondsworth, Middlesex: Penguin

Books Pvt. Ltd., 1964, 93-95. Printed.

Wills, Gary. Witches and Jesuits: Shakespeare's Macbeth. Oxford: Oxford University Press, 1995. Printed.

Yanhong, Xu. "Rebellious Personalities: A Female Perspective on Hedda Gabler" in Proceeding IX International Ibsen Conference. Pal BjorbyAarseth et al. Ovre Ervik: Acedemisk Forlog, 2001. Printed. 